This PDF is a selection from an out-of-print volume from the National Bureau of Economic Research

Volume Title: Tax Policy and the Economy: Volume 2

Volume Author/Editor: Lawrence H. Summers, editor

Volume Publisher: MIT Press

Volume ISBN: 0-262-19272-1

Volume URL: http://www.nber.org/books/summ88-2

Publication Date: 1988

Chapter Title: Did ERTA Raise the Share of Taxes Paid by Upper-Income Taxpayers? Will TRA86 Be a Repeat?

Chapter Author: Lawrence B. Lindsey

Chapter URL: http://www.nber.org/chapters/c10939

Chapter pages in book: (p. $131-160)$ 


\section{DID ERTA RAISE THE SHARE OF TAXES PAID BY UPPER- INCOME TAXPAYERS? WILL TRA86 BE A REPEAT?}

\section{Lawrence B. Lindsey}

Harvard University and NBER

\section{EXECUTIVE SUMMARY}

This chapter examines reasons for the rise in the share of taxes paid by upper-income individuals following the passage of the Economic Recovery Tax Act (ERTA) in 1981. It extends this analysis to estimate the potential revenue consequences of behavioral responses by taxpayers to the Tax Reform Act of 1986 (TRA86). Our major findings are as follows:

1. Wage, salary, and professional income constitute an increasingly large share of the income of upper-income taxpayers.

2. Lower tax rates on earnings and capital gains explain most of the redistribution of tax shares following ERTA.

3. Upper-income individuals received a declining share of dividend and interest income in spite of macroeconomic reasons to expect the opposite.

4. Higher tax revenues due to greater wage, salary, and professional income may increase expected tax revenues by as much as $\$ 15$ billion annually under TRA86.

5. Potential declines in capital gains realizations may lower expected tax revenues by as much as $\$ 30$ billion annually under TRA86, relative to a nonbehavioral estimation. 
6. The combined effect of all responses to TRA86 implies a decline in the share of taxes paid by upper-income taxpayers rather than an increased share expected under nonbehavioral assumptions.

\section{INTRODUCTION}

The existence of a substantial taxpayer response to the sharp reduction in the top tax rates under the Economic Recovery Tax Act (ERTA) is now generally accepted. In an earlier paper, Lindsey (1987a) estimated that this response was sufficient to generate as much tax revenue with a 50 percent top tax rate as would have been gathered if the earlier 70 percent rate had been maintained. In an investigation using a slightly different methodology, the Congressional Budget Office (1987, p. 501) concluded that:

The data show considerable evidence of a very significant revenue response among taxpayers at the very highest income levels. This finding of a strong revenue response in the top income group holds true for both projection methods and all target years.

On the other hand, there is little evidence of a substantial positive behavioral response to ERTA by lower- and middle-income taxpayers. In fact, the Lindsey and Congressional Budget Office (CBO) studies both noted that the income of lower-income groups was below predicted levels, just as the income of upper-income groups was above predicted levels. A number of explanations of this have been advanced. First, the data show that overall tax rates for many of these groups, including state income and Social Security taxes, showed little decline or actually increased over the period studied. ${ }^{1}$ Second, the income tax changes may have had little or no effect on economic growth. The simulation procedures used by Lindsey and CBO took the level of income as constant, implicitly assuming that taxes had no effect on growth. When this is coupled with the upper-income response, a redistribution of income away from lower-income taxpayers results. Third, these groups may not be tax sensitive. This may be due to limited knowledge of tax avoidance possibilities or difficulty in controlling the form of one's compensation and in changing the income from one's portfolio.

For whatever reason, the small response by lower- and moderate-income taxpayers, coupled with the large response by upper-income taxpayers, greatly raised the share of taxes paid by upper-income taxpayers. For

${ }^{1}$ Lindsey (1987a) found that the majority of taxpayers had increased marginal tax rates over the period due to increases in Social Security taxes and the effect of bracket creep on federal tax rates. 
example, taxpayers earning over $\$ 200,000$ paid more than 15 percent of total taxes in 1985, but this share would have been only 10 percent in the absence of a behavioral response by taxpayers.

Section 1 considers the magnitude of the revenue response by upperincome taxpayers in the period 1981-1985 as well as the changing nature of these high-income individuals. Often overlooked in the discussion of the behavior of upper-income taxpayers is the fact that the composition of income of these taxpayers has changed in recent years. In particular, the importance of salary and professional income has grown, and the importance of investment income has fallen.

Section 2 considers possible reasons why the behavioral response of upper-income taxpayers, as measured by the CBO and Lindsey studies, was substantially greater than that for lower-income taxpayers. The existence of taxpayer responsiveness to tax rates is well documented in such areas as labor supply, capital gains realizations, and the use of fringe benefits as compensation. We take a detailed look at some of the separate components of income in order to look for explanations of the response of taxpayers to ERTA.

The final section extrapolates the likely impact of TRA86 from these conclusions. That Act resulted in a reduction of the top marginal tax rate from 50 to 33 percent, with an even lower 28 percent rate for very-highincome taxpayers. If the taxpayer response to the latest tax reform parallels that following the 1981 Act, the tax share paid by upper-income individuals will rise further. However, the changes in the 1986 Act were more complex than in 1981. Some rates increased while others decreased. The final section examines the likely revenue consequences of these conflicting rate changes.

\section{CHANGES IN REVENUE AND TYPE OF INCOME AT THE TOP}

The Economic Recovery Tax Act of 1981 mandated a 23 percent phased reduction in tax rates between 1981 and 1984. The top tax rate was reduced from 70 to 50 percent beginning in 1982. Indexing of tax brackets was then begun in 1985. In addition, individual retirement accounts were extended to all taxpayers, and a partial exclusion of earned income for the lowerearning spouse of two-earner couples was enacted. In the absence of taxpayer response to lower tax rates, these provisions would have cost the Treasury some $\$ 110$ billion annually by the time they were fully phased in in 1985.

In analyzing the effects of taxpayer behavior on tax revenue, we must contrast the actual cost of the tax rate changes and the cost estimated under 
an alternative set of economic assumptions. This section begins with a brief description of the methodology involved. It then focuses on the changing composition of income for top-bracket taxpayers.

\subsection{Estimating the Actual Cost of Tax Rate Changes}

The actual revenue cost of these provisions cannot be known for certain; it is hypothetical. The revenue cost depends on how taxpayers would have behaved had ERTA not been enacted, and on the macroeconomic conditions that would have prevailed had the higher amount of revenue, associated with higher marginal tax rates, been collected by the government. To estimate the actual revenue cost, we must construct a predicted level and distribution of income, known as a baseline. This baseline is an estimate of what the level and distribution of income would have been had the tax cut not been passed. The baseline is constructed by pooling information on the income distribution in a year prior to the tax cut with changes in the level and composition of income between that earlier year and the year being studied.

The emphasis of this chapter, and of the Lindsey and CBO papers, is on the microeconomic behavior of individual taxpayers, not the effect of tax cuts on macroeconomic conditions. The macroeconomic conditions that actually prevailed during the period were taken as given. The revenue estimates that result from this approach do not, therefore, take account of the feedback effect of lower tax rates on macroeconomic activity. Only the redistribution of the shares of that activity among different income groups is measured.

To control for as many macroeconomic factors as possible in constructing the baseline, we set the level of income equal to the actual level of income for each component of personal income. That is, the baseline level of components of income such as wages, interest, dividends, and business income were each targeted to match the actual level of that component of income. Therefore, factors such as the rapid rise in interest income and interest rates were factored into the creation of the baseline. The changes in the overall distribution of income brought about by these macroeconomic factors are consequently also incorporated into the baseline. The residual difference between the actual and baseline distributions not caused by tax factors is minimized.

The resulting estimates of the effect of the tax rate cuts on tax revenue are shown in Figure 1. Tax revenue is shown under three different scenarios. The first scenario is that the old tax law is continued. In this scenario, the baseline level and distribution of income are applied to the old tax law and the resulting amount of tax computed. The second scenario predicts the level of taxes given the baseline income distribution under the new tax law. A comparison of these two lines shows the revenue cost of the tax law change assuming no change in taxpayer behavior. This comparison shows that the cost of the tax bill rises from about $\$ 5$ billion in 1981 to more than $\$ 110$ billion in 1985 . 


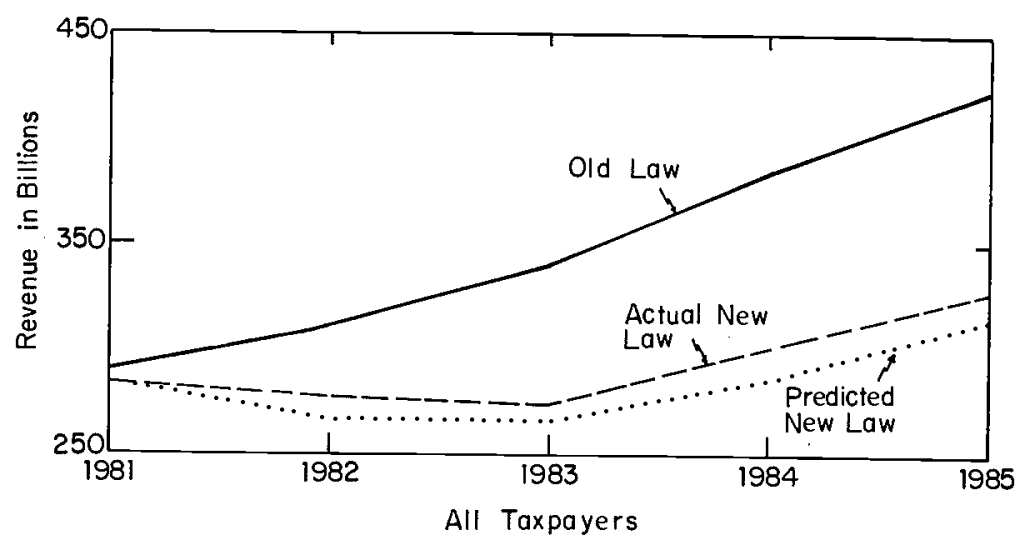

FIGURE 1. Actual and Predicted Tax Revenue

The third scenario presents the actual tax revenue collected in each year under ERTA. In Figure 1, this line runs between the old law and new law predictions. The distance between the actual revenue line and the old law line shows the actual revenue loss due to the tax law change. On the other hand, the distance between the actual revenue line and the new law line shows the additional amount of revenue loss that would have occurred had there been no behavioral response by taxpayers.

Figure 1 clearly indicates that the behavioral response made up only a small portion of the total revenue loss due to the tax bill. For example, in 1982 the added revenue amounted to about $\$ 11$ billion, or only one-quarter of the total prospective loss from the bill. In 1983 the behavioral response was only a bit more than $\$ 8$ billion, out of a total possible revenue loss of $\$ 75$ billion. In 1984 the response amounted to about $\$ 15$ billion out of a possible loss of $\$ 100$ billion, whereas in 1985 about $\$ 13$ billion was recaptured out of a possible loss of $\$ 110$ billion. These numbers suggest that only about 10 to 15 percent of the revenue loss from the ERTA tax cuts was recouped as a result of the behavioral response of taxpayers. The claim by some supply side economists that across-the-board rate reductions would produce added revenue is discredited by this data.

On the other hand, Figure 2 shows a different conclusion regarding the revenue collected from upper-income taxpayers-those earning over $\$ 200,000 .^{2}$ These data indicate that upper-income taxpayers paid more

\footnotetext{
2 In each year, baseline taxpayers were ranked by income. The figure presents the taxes paid by the same number of taxpayers in the baseline as had incomes over $\$ 200,000$ in each year. The result is that taxpayer groups are comparable in each of the years illustrated. Of course,
} 


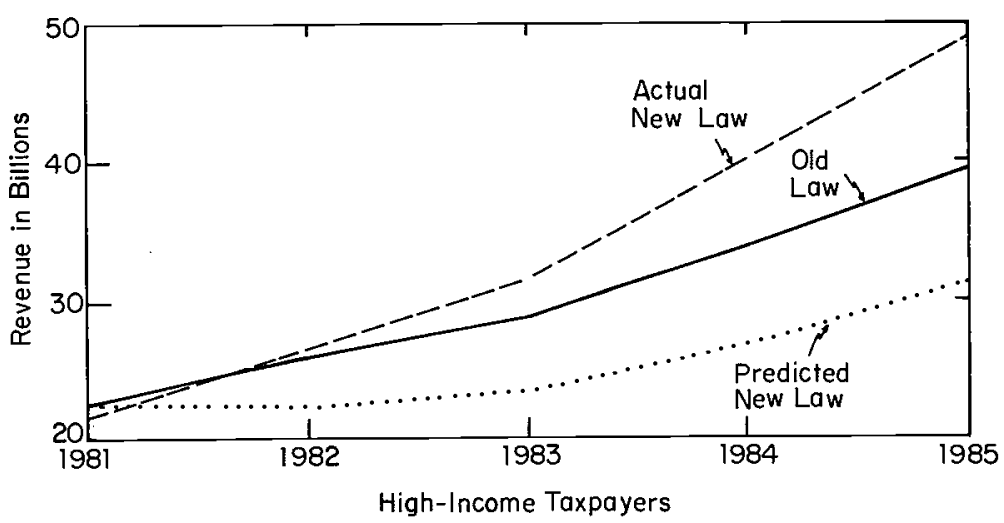

FIGURE 2. Actual and Predicted Tax Revenue

taxes under the new law than they would have paid under the old tax law. The difference between the old-law and predicted new-law figures shows that in the absence of a behavioral response, upper-income taxpayers would have received a substantial tax cut under ERTA. This scheduled tax reduction was about $\$ 3.5$ billion in $1982, \$ 5.5$ billion in $1983, \$ 7$ billion in 1984, and over $\$ 8$ billion in 1985.

The actual taxes paid under the new law exceeded the amount predicted by the baseline by substantial amounts. This difference is the amount of revenue attributable to taxpayer response. Upper-bracket taxpayers paid $\$ 4.2$ billion more than predicted in 1982 , $\$ 8$ billion more in $1983, \$ 13$ billion more in 1984, and nearly $\$ 18$ billion more in 1985 . In each year, this taxpayer response exceeded the scheduled amount of the tax cut. As a result, the Treasury netted $\$ 0.6$ billion more in 1982 from top-bracket taxpayers under the new law than the baseline predicted they would have under the old law. The comparable amounts of extra revenue are $\$ 2.7$ billion for 1983, \$6.3 billion for 1984, and \$9.6 billion for 1985 .

These data suggest that the across-the-board tax rate reductions of ERTA not only did not produce extra revenue but resulted in a significant decline in revenue. However, reductions in the top rate did increase total tax receipts from that income class. The combined effects of these two facts produced a sharp rise in the tax share paid by upper-income individuals.

the number of taxpayers earning over $\$ 200,000$ rose over the period, as did their incomes. Thus, intertemporal comparisons do not involve the same sizes of taxpayer groups. 


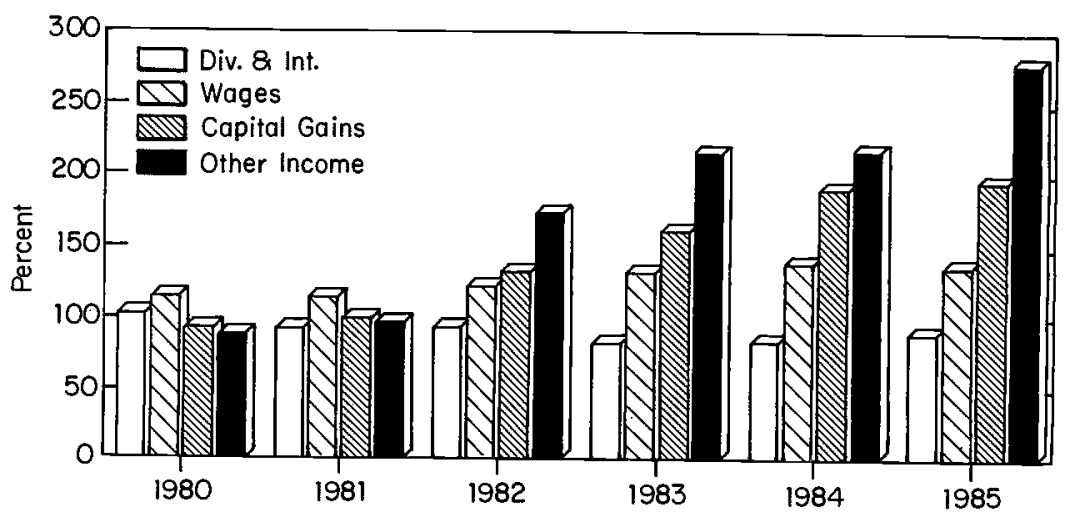

FIGURE 3. Actual as a Percent of Predicted Income, High-Income Taxpayers (Over \$200,000)

\subsection{Changes in the Composition of Top Incomes}

This revenue increase from upper-income individuals was the result of an increase in the taxable income they reported. Different components of income for upper-income taxpayers increased more than others in response to the tax rate changes. Figure 3 presents the ratios of the actual level of income to the level predicted by the baseline for four types of income: portfolio (dividends plus interest), wage and salary, capital gains, and "other." The last category is primarily composed of income from businesses, including partnerships, proprietorships, small business corporations, rents, and royalties, and is calculated by subtracting portfolio income, wages and salaries, and capital gains from adjusted gross income (AGI).

The figure indicates that greater reporting of income by upper-income taxpayers was due to greater reporting of business income, capital gains income, and wage income. The level of portfolio income reported by upper-income taxpayers was actually lower than predicted by the baseline.

The rising share of wage and business income and capital gains income in the total income ${ }^{3}$ of upper-income taxpayers is also indicated in an historical trend. It is inaccurate to think of top-bracket individuals as deriving the bulk of their income from passive sources such as interest and dividends. In 1983, only 21 percent of the income of the top 0.1 percent of the income distribution came from interest, dividends, and other non-

${ }^{3}$ For this analysis, total income represents AGI plus the excluded portion of capital gains, IRA contributions, Keoghs, and the two-earner deduction. It is comparable to the expanded income concept used by $\mathrm{CBO}$. 
capital-gains investment income. In contrast, 25 percent of the income of these top taxpayers came from earned sources.

This relatively high earnings share, and relatively low share of investment income, is a recent phenomenon. For sake of comparison, contrast 1983, the first year of economic expansion after the deep recession of 1981-1982, with 1975, the first year of expansion following the oil-shock recession of 1973-1974. After controlling for macroeconomic changes between 1975 and 1983, the top 0.1 percent of income recipients in 1975 received only 20.5 percent of their income from earned sources, compared with 24.7 percent in 1983 . The 1975 share of other capital income was 23.5 percent, compared with 21.3 percent in 1983 . Capital gains fell from 56 percent of their income in 1975 to 54 percent in 1983. In short, the earned share of compensation for these very-high-income taxpayers rose by more than 4 percentage points, or more than 20 percent, between 1975 and 1983.

This historic trend dates back at least to 1960 . Controlling for macroeconomic changes between 1960 and 1983, the top 0.1 percent of 1960 income recipients would have gotten only 14.7 percent of their income from earned sources. Of the rest, 34.1 percent came from capital gains, and 51.2 percent from other sources of capital income. Between 1960 and 1983, the 30percentage-point decline in the share of ordinary capital income in total income for these very-high-income taxpayers occurred. Roughly one-third of this represented a shift into wage income, and the remaining two-thirds comprised a shift into capital gains income. Figure 4 presents these changes in the income shares of the top 0.1 percent of taxpayers.

This change is even more dramatic when the top 2 percent of taxpayers are considered. Again controlling for macroeconomic changes, the earnings share in total income rose from 30.7 percent in 1960 to 48.3 percent in 1975 and to 55.1 percent in 1983. In contrast, the earnings from non-capitalgains investment income fell from 54.6 percent of income in 1960 to 27.8 percent in 1975 and to 18.6 percent in 1983. The capital gains share rose from 14.7 percent in 1960 to 23.9 percent in 1975 and to 26.3 percent in 1983. For the top 2 percent, the 36-point decline in ordinary capital income went about two-thirds into wages and one-third into capital gains. This is represented graphically by Figure 5 .

\section{DIFFERENT BEHAVIOR OF VARIOUS INCOME COMPONENTS}

The previous section considered the changes in the reporting of income by upper-income taxpayer groups. Not only did the share of income and taxes 


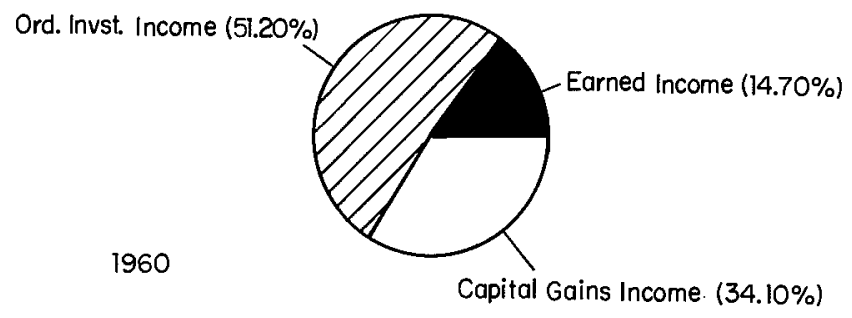

Ord. Invst. Income (23.50\%)

1975

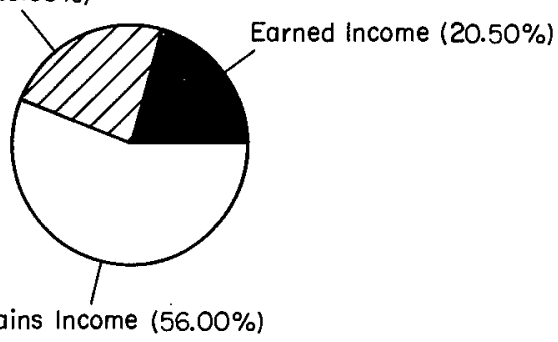

Ord. Invst. Income (21.30\%)

1983

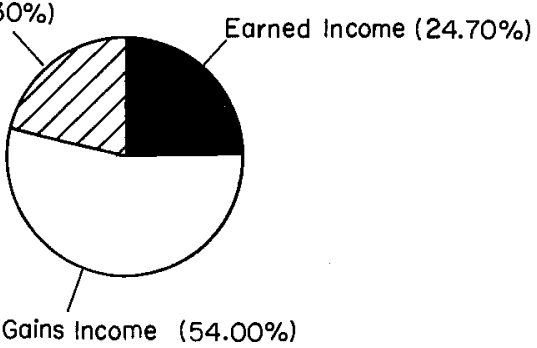

FIGURE 4. Sources of Income (adjusted for macroeconomic conditions of very-high-income taxpayers-the top $0.1 \%$ )

paid by top-bracket taxpayers rise when the top tax rate was reduced, the composition of income of these upper-income taxpayers also changed. By disaggregating the data into the individual components of income (wages and salaries, capital gains, business income, and interest and dividends), we can gather further information about the cause of these changes. 

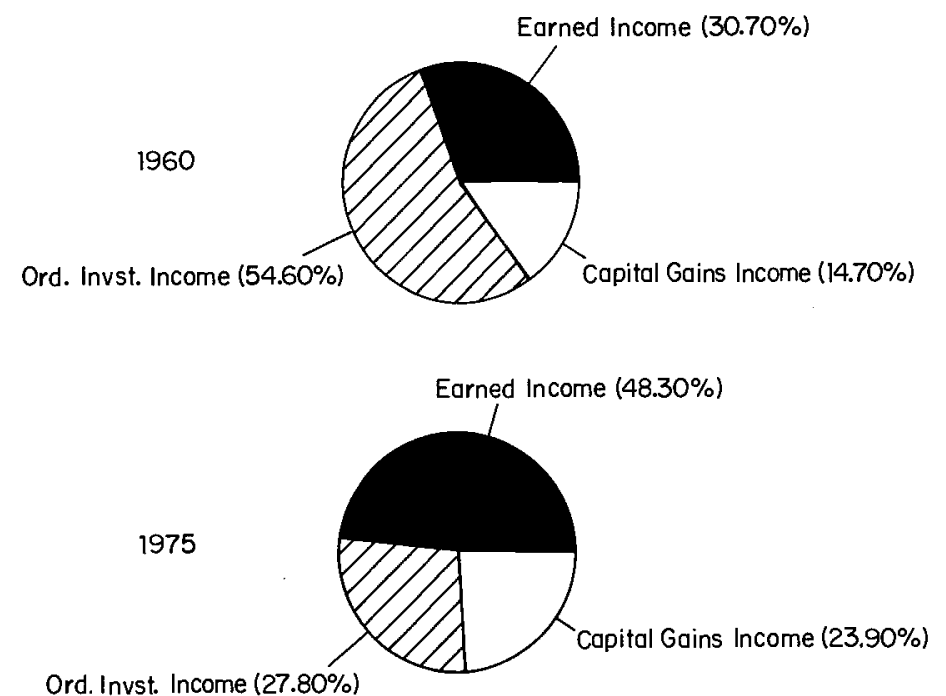

Ord. Invst. Income (27.80\%)

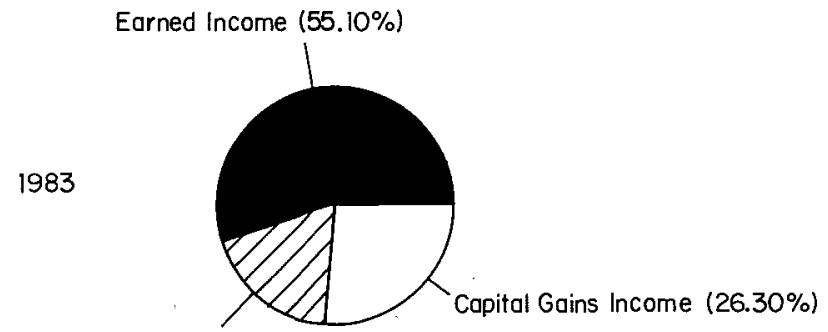

Ord. Invst. Income (18.60\%)

FIGURE 5. Sources of Income (adjusted for macroeconomic conditions of high-income taxpayers-the top 2\%)

\subsection{The Investigation of Behavioral Responses}

Note that the preceding analysis, indicating a rise in taxes paid by upper-income taxpayers, ignores what is usually termed "supply side" effects. That is, the effect of tax rate changes on the amount of labor and capital supplied to the economy is omitted from the analysis. This is necessary because the effect of such macroeconomic factors as monetary policy cannot be separated from the supply side effect of tax changes in 


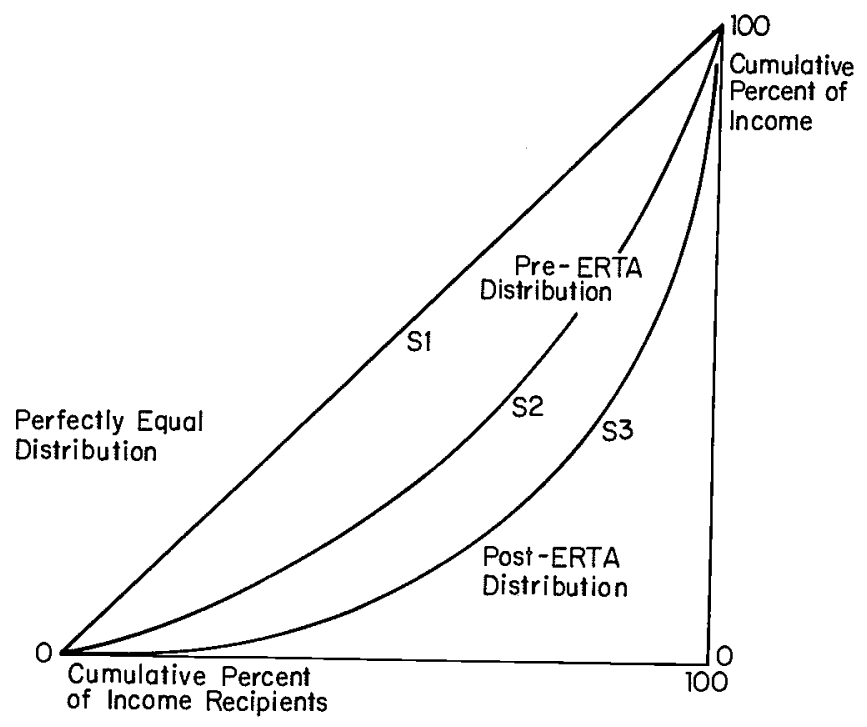

FIGURE 6. Perfectly equal distribution

determining the level of nominal income. Therefore, in determining the baseline level of income, we take the actual levels of each component of income as given, which is equivalent to assuming that there was no change in income due to supply side effects.

However, the existence of possible supply side effects can be discerned indirectly. Most of the nontax factors, such as monetary policy, that determine the level of a particular component of income have little or no effect on the distribution of that component of income. But the various tax rate changes are likely to have dramatic distributional consequences. These distributional consequences resulted from the differential reduction in tax rates applied to different recipients of each type of income. If the change in the actual distribution of income is systematically related to the change in the distribution of income that can be predicted using results from the literature, then a case exists that a tax-induced change in behavior occurred.

The test of the data for a behavioral response involves a two-step process. Figure 6 illustrates the first step in the test for a tax-induced behavioral change. It shows the calculation of the income distribution measure known as the Gini coefficient. The horizontal axis represents the cumulative percent of the population, and the vertical axis represents the cumulative percent of income. A line of perfect equality would be perfectly straight and connect the endpoints of the horizontal and vertical axes. Less 
equal distributions of income will be indicated by lines increasingly bowed in from this line of perfect equality. The Gini coefficient measures the inequality of the income distribution by comparing the ratio of the area between the actual distribution and the perfect equality line to the area of the triangle formed by the line of perfect equality and the two axes.

For most components of income, the distribution of income after the tax cut was less equal than the distribution of income before the tax cut. Figure 6 illustrates this with "pre-ERTA" and "post-ERTA" distributional lines. For this study the old-law line reflects the distribution of income in 1979, whereas the ERTA line reflects the distribution of income in 1983. The ERTA line is illustrated as more bowed in than the old-law line because of the less equal distribution of income in the latter year.

To test for the effectiveness of tax explanations for the observed changes in income, we created a simulated distribution of income based on the change in prevailing tax rates and an assumption about the amount of response expected from taxpayers drawn from existing research. In each case we start with the post-ERTA cut distribution of income and use tax rate changes to simulate what the distribution would have been had the pre-ERTA rates prevailed.

This simulated response can fall in any of three regions in Figure 6, indicated by S1, S2, and S3. If the simulation line is in region S1, then the simulation assumptions overpredict the actual behavioral response. That is, the actual distributional change turned out to be less than the distributional change predicted by the set of assumptions used. If the simulation line is in region $\mathrm{S} 2$, then the simulation assumptions underpredict the actual behavioral response. This can be because the chosen parameter is too small, or because some other effect correlated with income is at work. Finally, if the simulation line is in region $\mathrm{S} 3$, then the simulation assumptions wrongly predict the actual response. That is, the actual change went in the direction opposite to that predicted by the model.

The region in which the simulation line lays provides the qualitative answer regarding the existence of a supply side response. A quantitative answer regarding the predictive power of the simulated response can be tested by comparing the distribution of income in the tax simulation with the pre-ERTA and post-ERTA distributions. To determine the ability of the simulated response to explain the change in the distribution, we divided the continuous distribution shown in Figure 5 into twelve discrete segments. These segments are the bottom 25 percent, the 25 th-50th percentiles, the 50th-70th percentiles, the 70th-80th, 80th-85th, 85th-90th, 90th-95th, 95th-98th, 98th-99th, 99th-99.5th, 99.5th-99.9th, and the top 0.1 percent of income recipients.

The share of income received by each group is calculated for the 
pre-ERTA, post-ERTA, and simulated distributions. As noted above, the simulated distribution fell in area S2 of Figure 6. This means that the simulated distribution explained part of the change from the pre-ERTA distribution to the post-ERTA distribution. To calculate how much of the change was explained, we compared the variance between the pre-ERTA and post-ERTA distributions with the variance between the predicted and post-ERTA distributions. Dividing the latter variance by the former provides the share of the variance between the pre-ERTA and post-ERTA distributions explained by the simulated response. Under this measure, the closer the simulated response is to the post-ERTA distribution from which it originated, the less is the share of the variance that is explained. The closer the simulated response is to the pre-ERTA distribution, the greater is the share of the variance that is explained. This approach measures both the overall ability of the simulation parameters to explain distributional changes and the ability of that approach to explain the changes observed in particular income groups.

\subsection{Evidence of Omitted Supply Side and Pecuniary Changes}

3.2.1 Wage and Salary Income. The first test for supply side effects is performed in the area of wage and salary income. The economic literature suggests that the labor supply response of prime-age males is quite low, whereas the response for females tends to be quite high. The differential response is important because the ERTA provided for an extra marginal tax rate reduction for the lower-earning spouse in a two-earner family. This extra marginal rate reduction (equal to 10 percent of the regular rate) was directly targeted to the worker in the family likely to be most responsive to a tax rate change. Although the tax model we used does not specify the sex of the worker, it does provide separate data on the earnings of the higherand lower-earning spouses.

For simulation purposes, the labor supply elasticity of the higher-earning spouse with respect to the marginal share of compensation retained after tax was set equal to 0.1. The elasticity for the lower-earning spouse was assumed to be 1.0. The pre-ERTA and post-ERTA tax rates for each earner were computed. The post-ERTA earnings were reduced for each worker in accordance with the assumed elasticity and the change in the tax rate. The result was a simulated level and distribution of wage and salary income for each taxpayer unit. The distribution of this simulated result was then plotted and compared with the pre-ERTA distribution.

The elasticities chosen for the simulation are on the high side of the range of estimates of male and female labor supply elasticities in the literature. In spite of this, the simulated distribution of wage income is in region S2 on 


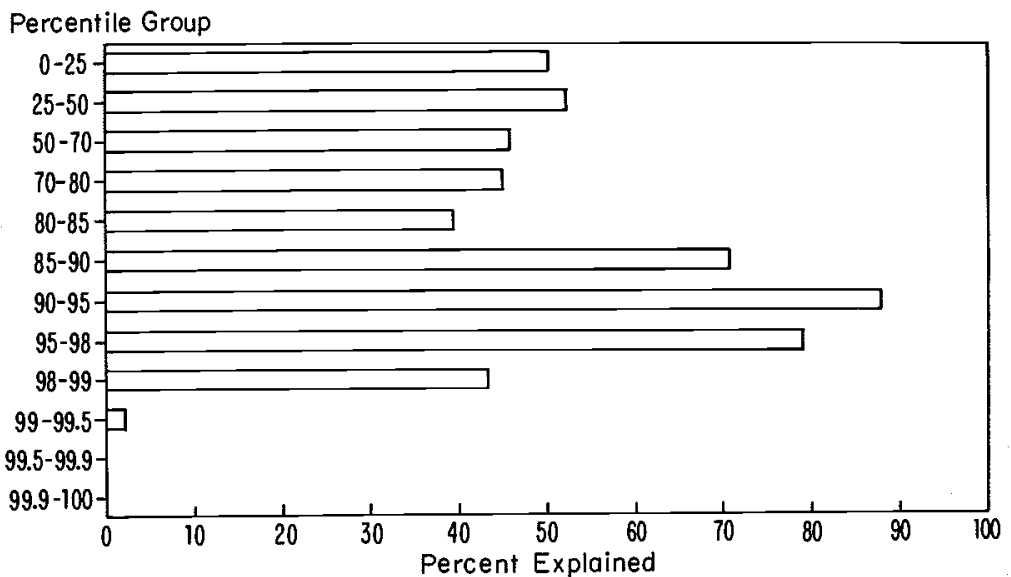

FIGURE 7. Labor supply response of wages (percent of variance explained)

Figure 6, implying that the assumed elasticities underpredicted the change in the distribution of wage and salary income.

Figure 7 illustrates the ability of the simulated response to explain the difference between the pre-ERTA and post-ERTA earned income shares for different income classes. The figure shows that the simulated response explained about half of the change in the income distribution for the bottom 99 percent of the taxpayer population. It was particularly effective at explaining the income change for the upper middle class-those between the 85 th and 98 th percentiles. These taxpayer groups had wage income between $\$ 40,000$ and $\$ 80,000$ in 1983 . On the other hand, the simulated labor supply response was unable to explain the enormous increase in the wage and salary income reported by the upper 1 percent of wage and salary recipients.

This provides an indication that at least some supply side change was at work. The change in wages and salaries in this simulation amounts to $\$ 38$ billion out of total wages and salaries of $\$ 1645$ billion, or a bit less than 2.5 percent. Of this change, $\$ 23$ billion, or 61 percent of the change, was due to the behavioral response of secondary earners ${ }^{4}$, whereas the response of

4 Corroborating evidence of an increase in female labor supply includes a dramatic decline of the difference between female and male unemployment rates beginning in 1982 and a rise in the ratio of female-to-male earnings at the same time. In 1982, for the first time since 1949, the adult female unemployment rate was below the adult male unemployment rate. In the fiveyear period during which this provision was in place, the adult female unemployment rate averaged 0.2 percent lower than the adult male unemployment rate. By contrast, in the fiveyear period immediately preceding 1982, the female unemployment rate exceeded the male 
primary earners and single earners amounted to only $\$ 13$ billion. This response is relatively small at the top of the income distribution because the importance of secondary earners incomes in total wages and salaries in that income range is quite small.

If this extra labor supply is attributable to the supply side effects of tax rate reductions, then ceteris paribus an additional $\$ 8$ billion annually was added to federal income tax collections. This occurs because the simulations described in section 1 took the economic conditions of the period as given. Had this extra labor supply not been forthcoming, the real level of wage income and the resulting level of tax revenue would have been lower.

However, this supply side response leaves about half of the change in the distribution of wages and salaries unexplained. One possible explanation for this unexplained residual is a switch from fringe benefits to wages as the preferred form of compensation. Given that fringe benefits are untaxed, a drop in the tax rate would indicate the greater likelihood for such a substitution.

Empirical evidence for a very high responsiveness of fringe share to tax rates is not present. However, evidence for modest responsiveness does exist. For example, work by Turner (1988) suggests that taxation of fringes under the pre-ERTA personal income tax would cause the fringe share of total compensation to fall by one-third. Because the changes under ERTA were far less dramatic than the full taxation of fringe benefits, a substantially smaller change in the fringe share of compensation would be expected. Turner's work suggests an elasticity of fringes with respect to federal tax rates of about 0.18 . Such an elasticity would imply that wage income was $\$ 30$ billion, or 1.8 percent, higher as a result of the switch from fringes to taxable wages.

Combining this elasticity assumption for fringes with the labor supply elasticities already reported produces a far better explanation of the change in the distribution of wage and salary income. Figure 8 illustrates the share of the variance between the 1979 and 1983 distributions explained by the simulated response. As the figure indicates, over 90 percent of the distributional change in the upper middle class is now explained. Between 50 and 80 percent of the change was explained for the bottom 80 percent of the income distribution. (The result shown for the 80th-85th percentile is low because 1979 and 1983 income shares for this group were quite similar.)

Furthermore, there is some evidence that this fringe benefit explanation

unemployment rate by an average of 1.2 percentage points. In the ten-year period preceding 1982 , the female unemployment rate exceeded the male unemployment rate by an average of 1.3 percent. The earnings of full-time year-round female workers rose to an average 63 percent of the earnings of full-time year-round male workers in the first year that ERTA was in effect, after having been just 60 percent for each of the preceding eight years. The average of this ratio since ERTA took effect has been 64 percent. 


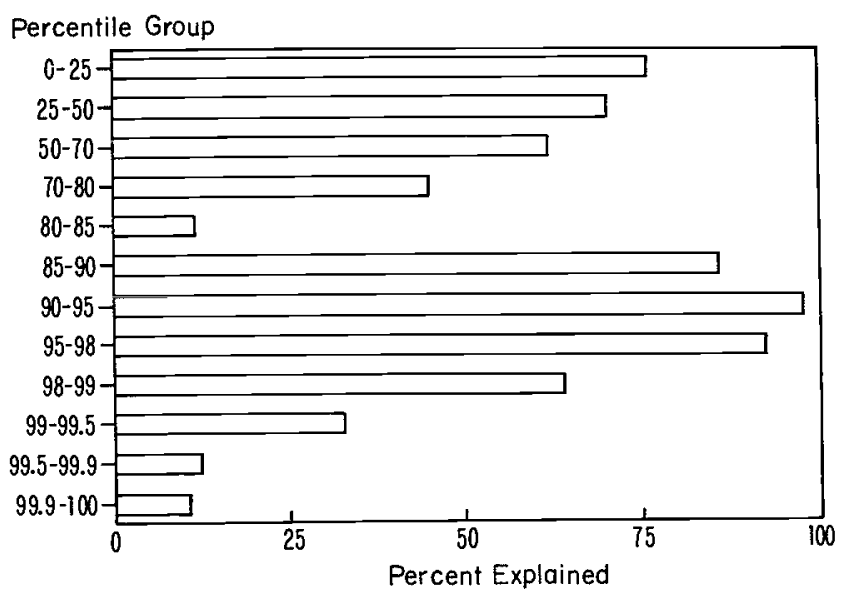

FIGURE 8. Labor supply and fringe response of wages (percent of variance explained)

had some effect at the top of the income distribution. Roughly one-third of the variance for the bottom half of the top percentile is explained by the fringe benefit effect. The combined explanatory power of labor supply and fringe benefit effects is about 10 percent for the very top earners, compared to nil explanatory power for the labor supply effect by itself. The fringe elasticity of 0.18 was derived from data on middle-income workers and applied to all groups. Had a variable elasticity simulation been performed, with a higher elasticity for upper-income taxpayers, a greater explanatory power would most likely have resulted.

The revenue effect of the reduction in fringe benefits induced by ERTA's rate reductions would amount to an additional $\$ 6$ billion of federal income taxes annually. It is important to consider whether this extra revenue is permanent or simply an acceleration in the payment of taxes. In large measure the answer depends on the type of fringe compensation given up. Fringe benefits in the form of pension contributions produce future taxes when the taxpayer receives the pension benefits. On the other hand, office "perks" and insurance-type fringe benefits provide untaxed future benefits. In this latter case, the extra taxes received are not at the expense of future tax payments.

Turner's data show that pension benefits and insurance benefits make up roughly equal shares of total fringes. His results suggest that pension benefits are probably less sensitive to taxes than are insurance benefits, 
implying that less than half the reduction in fringes was due to a reduction in pension benefits.

Furthermore, the amount of forgone taxes on future pension benefits is likely to be far less than the taxes gained in the present by smaller pension contributions. To avoid the issue of present value, we can assume that the pension contributions grow in value at a rate equal to the rate of discount of future tax liability. The only difference in tax revenues will be due to the differential taxation of wage and pension income. In the aggregate, the marginal tax rate on wage income is 22 percent under the new tax law but only 19 percent on pension benefits. In fact, since pension contributions accrue primarily to upper-income workers, this greatly understates the extra taxes from wages. Furthermore, wages are subject to social insurance contributions, but pensions are not. This would add an additional 14 percent to the total federal taxes received and raise the federal tax burden on wages to 36 percent. In sum therefore, the extra revenue forgone from lower future pension benefits is less than half the extra revenue received in the present from lower pension contributions. Because less than half of the switch from fringes to wages is in the form of pensions, it is safe to assume that less than one-quarter of the revenue gained in the present from the switch in form of compensation is at the expense of future revenue.

The extra revenue received from the switch from fringe benefits to wages cannot be considered a supply side response because no additional factor supplies are forthcoming. Instead, a pecuniary change has occurred in the form of compensation that a worker receives.

Although no extra economic growth is attributable to the change, this fringe benefit effect raises wages and salaries relative to what they otherwise would have been. The level of wage and salary income in the baseline income distribution described in section 1 was overstated. As a consequence, the behavioral response to the tax rate reduction was understated. To measure the true behavioral response to the tax changes, we must add the labor supply and fringe benefit effects to the effects measured in section 1 .

The supply side and pecuniary changes in wage and salary compensation provide two possible explanations of the enormous behavioral response of upper-income taxpayers relative to other taxpayers. If these responses were neglected in forming the baseline income distribution, then the actual response of middle- and upper-middle-income taxpayers is much larger than previously estimated. This would make the total responses of upper-income and moderate-income taxpayers more comparable. As Figure 7 showed, the labor supply and fringe benefit simulation had relatively little explanatory power at the very top of the income distribu- 
tion, but it was a signficant factor at other levels, thus indicating that the ignored response was at these lower levels.

3.2.2 Business Income. As in the case of wage and salary income, the possibility of an omitted supply side response exists in the case of business income. As the data presented in the first section indicated, business income-income from proprietorships, partnerships, small business corporations, farms, rents, and royalties - rose far more rapidly than predicted for upper-income taxpayers. Part of this response might be a supply side response of these individuals working harder. However, applying labor supply elasticities from the literature to the changes in after-tax compensation due to ERTA produces a labor supply response that is far smaller than the observed rise in business income. The likelihood of a supply side response being the dominant factor in the change in business income is therefore likely to be remote.

However, individuals who own their own businesses have a substantial ability to convert taxable business income into untaxed business expenses. Work by Clotfelter, for example, indicates that the travel and entertainment expenses of small firms is highly sensitive to the after-tax cost of the compensation. These businesses also have a greater capacity to convert current income into insurance and pension benefits than does the population at large.

The test for tax effects on business income is performed in the same manner as the tests on wage and salary income. Empirical estimates of the effects of taxes on proprietorship and partnership decisons do not exist. Therefore, an arbitrary selection of 0.56 was made. This value assumes that business income is derived from primary earners with a labor supply elasticity of 0.1 and a fringe elasticity of 0.18 . It further assumes that small businesses are twice as responsive as large firms to the tax effects on their owners. Simulations done using this elasticity place it in region S2 of Figure 4 , indicating an underprediction of the actual effect by the model.

Figure 9 shows that over half the variance between the pre-ERTA and post-ERTA distributions is eliminated by the simulated response to the tax rate changes. The results in Figure 9 show that the tax changes were particularly effective in explaining the variance in the share of earnings received by middle-income professionals and proprietary businesses. However, in the case of income at the top of the business income distribution, only about half of the variance was explained. This, coupled with a similar result for top-bracket wages, suggests that additional factors are at work.

As in the case of wages, some of the extra revenue resulting from the response of taxpayers to the change in tax rates is transitory. As discussed previously, pension contributions that are currently untaxed will eventu- 


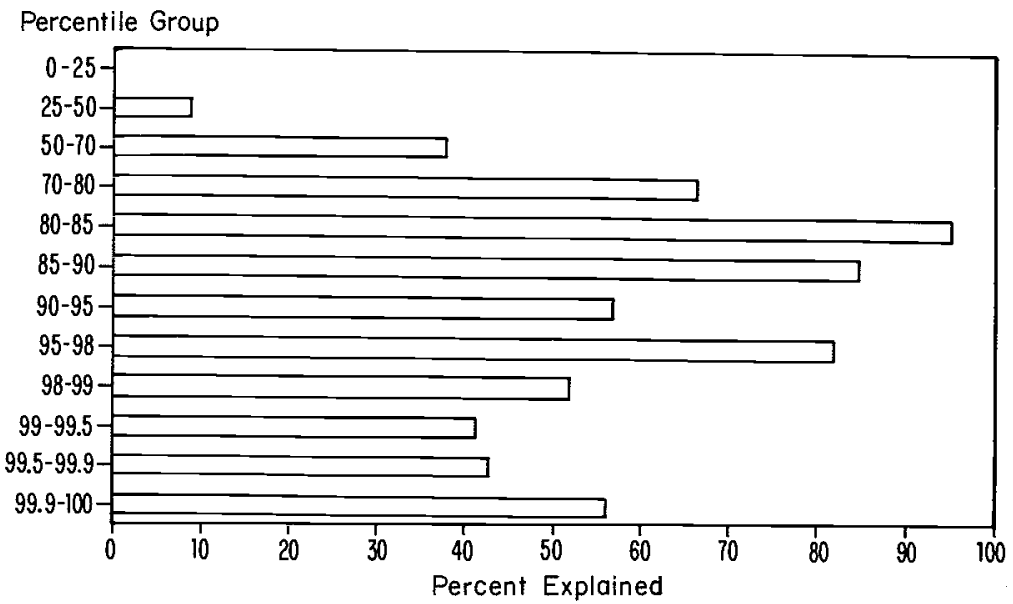

FIGURE 9. Response of Business Income (percent of variance explained)

ally produce pension income that will be subject to tax. The more complex types of deferred benefit packages are subject to the same analysis. Furthermore, a case can be made that the tax bracket of these taxpayers is less likely to drop when the benefits are received because they tend to be near the top of the income distribution. This would suggest that a greater degree of the revenue gain from extra business income is less likely to be transitory for these taxpayers than it is for the population as a whole.

On the other hand, taxpayers receiving business income are more able to change their compensation between taxable income and consumption-type perks such as travel and entertainment. The transformation of perks into taxable income may change the consumption mix of the individual, but this change will not alter the amount of tax liabilities generated from other sources or at a later date. This type of behavioral change will produce a revenue gain that is more likely to be permanent and not offset by tax effects.

3.2.3 Capital Gains. The evidence that capital gains realizations are sensitive to tax rate changes has been demonstrated by many researchers (Auten and Clotfelter (1983), Feldstein and Yitzhaki (1977), Lindsey (1987b), Minarik (1981), and U. S. Department of the Treasury (1986)), although the magnitude of the response is far from certain. In addition, macroeconomic factors contributed to the level of capital gains realizations as well as tax changes.

The baseline income distribution that underlies this study assumes that, 
absent any tax changes, capital gains realizations rise at the same rate as "tradable" household wealth. Tradable household wealth is composed of corporate equities, real estate, and the value of unincorporated businesses as estimated in the Federal Reserve Board's Flow of funds.

One can distinguish between the effects of macroeconomic factors, such as the rise in household wealth, and the effect of tax changes. An overall rise in wealth would be likely to cause an increase in the level of capital gains, but not a redistribution of the share of capital gains received by different taxpayers. On the other hand, a tax rate reduction is likely to cause both a rise in the overall level of realizations and a change in the distribution of those realizations, reflecting the different changes in incentives for different taxpayers under ERTA. If the change in the distribution of capital gains resembles the distributional change predicted by behavioral simulations of the response of capital gains realizations to tax changes, then the tax changes are the likely cause of the rise in capital gains.

The test of the hypothesis that tax-induced changes were at work resembles the tests performed to check for tax effects in the distribution of wages. The 1983 level and distribution of capital gains realizations was adjusted to take account of the changes in marginal tax rates between 1979 and 1983. An elasticity of capital gains realizations with respect to an after-tax share of 5.2 was selected to simulate the tax effect using the result from Lindsey (1987b). This elasticity is equivalent to an elasticity of 0.8 with respect to the tax rate.

The simulation placed the distribution line in region S2 of Figure 6, indicating that the assumption underpredicted the actual change. However, the simulated distribution was quite close to the pre-ERTA distribution, indicating a high degree of explanatory power by the simulation. Figure 10 shows the amount of variance between the 1979 and 1983 distributions, which was explained by the tax effect. On average, the simulation explained over 80 percent of the variance between the 1979 and the 1983 distributions.

It should be stressed that any behavioral response to changes in capital gains tax rates is not supply side in the usual meaning of the term. The observed response of extra realizations is not evidence that existing supplies of capital are brought forth as a result of the tax change. It might be argued that the existing stock of capital is more likely to be efficiently allocated with the lower capital gains tax rate, since taxpayers are less likely to be locked in to their existing portfolios because of tax considerations. It might also be argued that lowering the total tax rate on capital income will increase the rate of savings on the margin above what it otherwise would have been. However, the benefits of such changes are only likely to evolve 


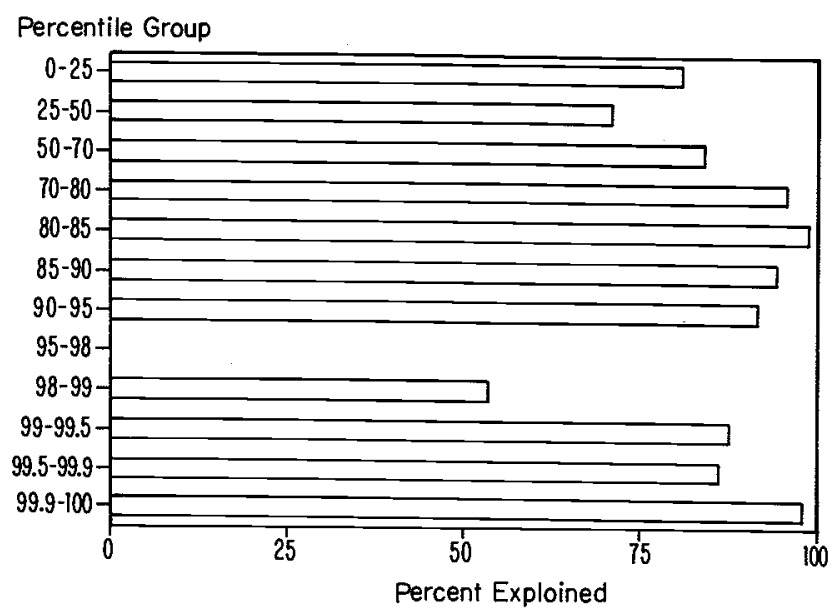

FIGURE 10. Response of Capital Gains (percent of variance explained)

over a long time and are probably too small to be observed in the existing data.

The revenue gain from such a change in capital gains realizations might best be termed pecuniary rather than supply-side because the behavioral response represents a rearrangement of the existing supply of capital rather than an increase in the overall quantity. This rearrangement of portfolios raises the further question of whether this revenue gain is permanent or temporary.

\subsection{The Surprising Case of Ordinary Investment Income}

The period between 1979 and 1983 was one of rapidly rising interest and dividend income for taxpayers as a whole. Interest and dividend income rose by $\$ 97$ billion between 1979 and 1983, or by 90 percent. This was nearly three times as fast as the growth in AGI over the same period. Furthermore, interest and dividend income is highly concentrated among upperincome brackets. For example, the top 1 percent of interest and dividend recipients receive about a quarter of total income from these sources.

The combined effect of the sharp rise in interest and dividends and the concentration of that income among high-income taxpayers would be a large redistribution of total personal income toward top-bracket taxpayers. Further enhancing this expectation are indications that the share of wealth in the country, which produces interest and dividend income, held by the top of the income distribution may have increased. In addition, the tax rate reduction and increase in after-tax share for top-bracket taxpayers was at 
least as dramatic in the case of interest and dividend income as it was in the case of wage and professional income. All of these factors would lead to the expectation that the increased share of income received by upper-income taxpayers between 1979 and 1983 would be due in part to the overall rise in capital income.

This turns out not to be the case. Greater interest and dividend income was not a factor in the increase in the share of total income received by the top 1 percent of the income distribution. The total income of this group was nearly $\$ 23$ billion higher than it would have been had its share of income remained unchanged. Of this figure, $\$ 22$ billion can be explained by the rising share of capital gains income and a further $\$ 8$ billion by the rising share of earned income. The net change in the share of interest and dividend income was a negative component in contributing to the higher share of total income received by the top 1 percent. This result is one of the most unexpected findings in the tax data.

The reason for this is a sharp reduction in the share of interest and dividend income received by the top recipients of this income. Unlike the other types of income considered, the share of income from interest and dividends received by upper-income taxpayers was lower in 1983 than in 1979. The top 1 percent of recipients of this type of income received 27.1 percent of interest and dividend income in 1979 and 23.2 percent in 1983.

This decline in the share of interest and dividend income received at the very top did not move to the bottom of the distribution, however, but stayed in the top half of the income distribution. The lower half of interest and dividend recipients received the same share of interest and dividend income in the two years: 2.2 percent. On the other hand, taxpayers in the 50th to 90th percentiles of interest and dividend income recipients saw their share rise from 30 to 33 percent. Taxpayers in these percentile classes typically received between $\$ 300$ and $\$ 5000$ in interest and dividends in 1979 and between $\$ 600$ and $\$ 9000$ in interest and dividends in 1983.

Tax law changes are unlikely to account for this change. If saving is positively related to the after-tax share of portfolio income kept by the taxpayer, then a redistribution of this income to top-bracket taxpayers would be indicated. The pattern of response would be similar to that seen in the cases of wages, capital gains, and business income.

In this case, an institutional factor can be identified to explain this data. Money market mutual funds became widely available between 1979 and 1983. Furthermore, the deregulation of the banking system afforded savers with moderate-sized portfolios saving instruments that yielded market interest rates previously available only to the very wealthy. Taxpayers with small portfolios probably had fewer increases in the options available to them than did taxpayers with portfolios of $\$ 10,000$ or more. Thus, the share 
change did not extend down to the bottom half of the distribution of income and dividend recipients.

The revenue consequences of this institutional change are likely to be negative. The opening of these money market accounts either raised the total cost of borrowing above what it otherwise would have been or reduced the spreads of financial intermediaries. It probably had the added effect of lowering the return to lenders other than those who availed themselves of these new financial instruments. The tax status of these groups can be compared. The taxpayers with the new money market accounts were in an above average personal tax bracket, say 30 percent, but well below the top rate. On the other hand, final borrowers and financial intermediaries are taxed at the marginal corporate rate of 46 percent. Lenders who previously had access to market rates were probably also at or near the top marginal personal rate of 50 percent. Thus, the beneficiaries of these accounts had lower marginal tax rates than those whose income may have declined due to the new accounts.

\section{TAXPAYER BEHAVIOR AND THE 1986 TAX REFORM}

The previous section described a number of possible behavioral phenomena that followed the tax rate reductions of the 1981 Tax Act. TRA86 continued the rate-cutting tradition of the earlier act. The maximum tax rate on ordinary income was reduced from 50 to 33 percent, with a further reduction to 28 percent for very-high-income taxpayers. Unlike the 1981 Act, TRA86 aggressively expanded the income tax base. The expansion of the base offset in large measure the potential revenue loss from the reduction in tax rates.

This section examines the potential effects of the base broadening and rate reduction in the 1986 Act. The possible supply side ramifications of rate reductions are considered as well as the revenue effects of pecuniary changes in taxpayer behavior. The revenue estimates presented here are intended to convey only the potential magnitude of supply side assumptions; they do not represent a forecast of what is likely to happen.

As in the case of the analysis presented earlier, the major potential behavioral response involves top-bracket taxpayers. These taxpayers will have the largest reduction in their tax rates and the greatest increase in the after-tax share of income. The earlier analysis also indicated that the degree of responsiveness to tax rate changes may also be greater for upper-income taxpayers than for the taxpaying population as a whole. For all of these reasons, the magnitude of revenue response at the top of the income distribution is the key to whether or not TRA86 is revenue neutral as claimed, raises taxes, or reduces taxes. The magnitude of the behavioral 
response will also determine whether the share of taxes paid by upperincome taxpayers will rise, as it did after the 1981 Tax Act, or fall.

\subsection{Revenue Estimates With No Taxpayer Behavior}

The first step in simulating the effect of the 1986 Act is the creation of a baseline income distribution for a year in which the new law will be in effect; 1988 was selected. The baseline for a future year involves a procedure not required for simulating a past event: forecasting future macroeconomic levels. The use of any economic forecast necessarily creates added uncertainty regarding the accuracy of the revenue estimates, because actual economic conditions may differ from those forecast. For these simulations, the economic forecast contained in the 1988 budget of the United States was used.

The 1988 baseline income distribution was extrapolated from the 1983 Individual Tax Model File Public Use Sample using the NBER TAXSIM model. The resulting distribution presumes that taxpayers behave as they behaved in 1983, the year from which the original data are obtained. Each taxpayer is allotted a higher income level, reflecting economic growth over the period, and a different composition of income, reflecting the forecast change in economic conditions between 1983 and 1988. Any possible behavioral response by the taxpayers to the new tax rates implied by the change in income and the new tax law are ignored in the first set of simulations.

Table 1 presents the results of these simulations. Taxpayers are classified by income class based on the definition of adjusted gross income in a fully phased-in version of TRA86. The total tax paid by taxpayers in that income group is reported for three different tax laws: the old or prereform tax law, the TRA86 tax law for the year 1988, and a fully phased-in version of TRA86. The latter two laws differ in that some of the new base-broadening provisions of the TRA are only partially implemented in 1988.

The table shows that absent any behavioral response, the new tax law will raise taxes on all income groups earning over $\$ 50,000$, and lower taxes on all income groups earning less than $\$ 50,000$. Given the 1988 tax rules, this will mean that total taxes will be about $\$ 2.6$ billion higher under the new tax bill than under the old tax bill. Taxpayers earning over $\$ 200,000$ will pay $\$ 4.6$ billion more, and taxpayers earning between $\$ 100,000$ and $\$ 200,000$ will pay $\$ 3.1$ billion more. Each figure represents an 8 percent increase in taxes. In contrast, taxes for taxpayers earning under $\$ 10,000$ will be cut nearly in half, and those for taxpayers earning between $\$ 10,000$ and $\$ 20,000$ will decline by about 10 percent. In total, the share of taxes paid by taxpayers earning over $\$ 50,000$ will rise from 54.0 percent under the old law to 56.7 percent under the new law. 
TABLE 1

Tax Revenue Assuming No Behavioral Response

\begin{tabular}{lccc}
\hline $\begin{array}{l}\text { Income } \\
\text { class }\end{array}$ & Old tax law & $\begin{array}{c}\text { TRA86 } \\
\text { 1988 rules }\end{array}$ & $\begin{array}{c}\text { TRA86 fully } \\
\text { phased in }\end{array}$ \\
\hline Under 10 & 3.2 & 1.7 & 1.8 \\
$10-20$ & 28.2 & 25.5 & 25.9 \\
$20-30$ & 44.4 & 43.3 & 44.0 \\
$30-40$ & 51.7 & 50.0 & 50.8 \\
$40-50$ & 47.8 & 46.2 & 47.3 \\
$50-75$ & 78.8 & 80.9 & 82.9 \\
$75-100$ & 32.1 & 34.2 & 35.3 \\
$100-200$ & 38.8 & 42.3 & 74.3 \\
Over 200 & 61.7 & 68.4 & 403.3 \\
Total & 386.6 & 392.5 & \\
\hline
\end{tabular}

All numbers are for calendar 1988.

Income classes are in thousands.

Revenue figures are in billions.

The table also shows that the phase-out provisions of the new tax law involved $\$ 10.9$ billion of revenue in 1988 . Although all groups would see their taxes rise if the phase-out provisions were eliminated, most of the extra revenue would come from upper-income taxpayers. Nearly onequarter of the revenue consequences of the phase-out provisions involve taxpayers with incomes over $\$ 200,000$, whereas more than 70 percent of the phase-out revenue involves taxpayers with incomes over $\$ 50,000$. Therefore, as the tax provisions are phased out, the share of tax payments by upper-income taxpayers will continue to rise. If these provisions were fully subject to tax in $1988,57.1$ percent of taxes would be paid by taxpayers earning more than $\$ 50,000$.

These results indicate that absent any behavioral response by taxpayers, the new individual income tax provisions will increase personal income tax revenue. Furthermore, they show that the 1986 Act increased the share of taxes paid by upper-income taxpayers, even though the tax rate on these taxpayers dropped dramatically. This is evidence that the base broadening more than compensated for the lower tax rate.

\subsection{The Potential Taxpayer Response}

Previously, we identified a number of possible supply side and pecuniary responses that taxpayers might undertake. On the supply side, increased real wage income would result from increased labor supply. The same would occur in the case of professional income. In addition, pecuniary 
reallocations of compensation into taxable wages along with out-of-taxexempt compensation would be likely to result from the tax rate reduction. On the other hand, the 1986 Act produced the largest increase in capital gains tax rates on record. This would cause fewer capital gains to be realized and cause tax revenue to decline relative to the no-behavior revenue figures.

These potential responses were simulated separately for each of the types of income involved: wages, professional income, and capital gains. The elasticities used were the same as those used in the previous section. For wages, a labor supply elasticity with respect to after-tax share of 0.1 was used for single individuals and for the higher earner in married couples. An elasticity of 1.0 with respect to after-tax share was used for the wages of the lower-earning spouse if both spouses worked. Turner's fringe benefit elasticity of 0.18 was added to each of these figures. For professional and proprietary income, an elasticity of 0.56 with respect to the after-tax share was used. Finally, a capital gains elasticity of 4.5 with respect to the aftertax share was used in the simulation of taxpayer response to the increase in the capital gains tax rate. A final simulation was also run, which incorporated the effects of all of these responses. The total effect might differ from the sum of the individual effects due to the interaction of different types of income in determining a taxpayer's taxable income and tax rate.

As stated previously, these elasticities should not be considered precise estimates or predictions. They were selected in order to estimate an order of magnitude for any potential taxpayer response. As such, these estimates tend to err on the high side. Readers who feel that the behavioral parameter is twice as high as it should be will find that a revenue effect half as large as estimated is in line with their prior expectations.

It is also important to note that these simulations presume that any supply side response would be reflected in a higher level of nominal income. In fact, this is unlikely to be the case. Given a constant monetary policy, a rise in labor supply will increase nominal income by less than it will increase real income. These simulations therefore overstate the rise in nominal tax revenue that would result from the simulated supply side response. They represent the change in revenue that would be expected at a given level of prices and rate of inflation.

Table 2 presents the revenue results from each of the simulations of these behavioral responses. In each case, the behavioral simulation was performed at 1988 income levels, assuming that TRA86 was fully phased in. The revenue effect is given for each income class based on the new law's fully phased-in definition of adjusted gross income.

The table shows that the simulated behavioral response of wages would produce an additional $\$ 13.8$ billion of revenue, or about 3.5 percent more 
TABLE 2

Potential Revenue Impact of Behavioral Responses

\begin{tabular}{lcccc}
\hline \multirow{4}{*}{$\begin{array}{l}\text { Income } \\
\text { class }\end{array}$} & $\begin{array}{c}\text { Wages and } \\
\text { salaries }\end{array}$ & $\begin{array}{c}\text { Business } \\
\text { income }\end{array}$ & Capital gains & $\begin{array}{c}\text { All } \\
\text { responses }\end{array}$ \\
\hline Under 10 & -0.1 & -0.0 & -0.1 & -0.2 \\
$10-20$ & -1.4 & -0.0 & -0.2 & -1.6 \\
$20-30$ & +0.1 & +0.0 & -0.5 & -0.4 \\
$30-40$ & +2.0 & +0.1 & -0.6 & +1.5 \\
$40-50$ & +0.8 & +0.1 & -0.8 & +0.1 \\
$50-75$ & +2.7 & +0.2 & -2.7 & +0.2 \\
$75-100$ & +2.6 & +0.2 & -2.3 & +0.5 \\
$100-200$ & +3.0 & +0.5 & -5.3 & -1.8 \\
Over 200 & +4.4 & +0.5 & -18.4 & -13.5 \\
Total & +13.8 & +1.6 & -30.8 & -15.5 \\
\hline
\end{tabular}

All figures for 1988.

Income classes are in thousands.

Revenue effects are in billions.

than expected. Of this additional revenue, 53 percent would be derived from taxpayers with incomes over $\$ 100,000$ and 91 percent from taxpayers earning more than $\$ 50,000$. This extra tax revenue results from a $\$ 57$ billion, or 2.4 percent, rise in total wage and salary income. A 17 percent rise in wage income for taxpayers earning more than $\$ 200,000$ is indicated. More than one-quarter of the total rise in wage and salary income will accrue to taxpayers in this income class, and nearly three-quarters will accrue to taxpayers earning more than $\$ 50,000$. The share of wages and salaries received by taxpayers earning more than $\$ 50,000$ will rise from 35.3 to 36.2 percent. These changes in the distribution of wage and salary income are of roughly the same order of magnitude as the changes that followed the 1981 Tax Act.

Table 2 indicates that professional and proprietary income would rise enough to generate $\$ 1.6$ billion in extra revenue in 1988 , given the simulation parameters described above. This extra revenue would result from a $\$ 6$ billion increase in business and professional income, a 6 percent increase.

In sum, the simulated potential increase in revenue from greater labor supply and lower fringe benefits amounts to $\$ 15.5$ billion. To individuals not familiar with the magnitudes involved in the federal budget, this may seem like a large number. However, it amounts to slightly less than 4 percent of personal income tax revenue and roughly 1.5 percent of total 
federal revenue. It represents the extra revenue produced from a typical year's economic growth of 2.5 to 3.0 percent. In short, potential supply side responses should not be relied on to balance the federal budget or to be sufficient to finance further marginal tax rate reductions.

In addition, although the wage, salary, and professional income responses will produce more tax revenue than predicted by the behavior-free model, the reverse is true for capital gains behavior. The 1986 Act mandated the largest increase in capital gains tax rates on record. Absent a behavioral response, this tax rate increase would boost tax revenues by roughly $\$ 15$ billion in 1988 . This $\$ 15$ billion increase is factored into the revenue estimates presented in Table 1 . There is general agreement that at least some reduction in capital gains realizations will result from this tax rate increase, however (Turner (1988)). Thus, the behavior-free revenue estimates in Table 1 exaggerate the amount of tax revenue that will be collected.

To estimate the magnitude of the possible revenue effect, an elasticity of 4.5 with respect to the after-tax share was used. The third column in Table 2 presents the revenue consequences of such an assumption. Total revenue declines $\$ 30.8$ billion due to the reduced realization of capital gains. This represents 7.7 percent of total personal income tax revenue and twice the simulated response of wage, salary, and professional income.

The table also shows that the great majority of this revenue decline would occur among upper-income taxpayers. Fully 60 percent of the decline would occur among taxpayers earning over $\$ 200,000$, and 93 percent of the revenue decline would occur among taxpayers making over $\$ 50,000$. This would have a dramatic effect on the share of taxes paid by different income groups. Taxpayers earning more than $\$ 100,000$ would see the share of taxes they pay drop from 29 percent under the behavior-free simulation to 25 percent. The share of taxes paid by taxpayers earning under $\$ 40,000$ would rise from 30 to 33 percent. In short, the potential behavioral response to the capital gains tax changes would have important distributional consequences as well as a substantial effect on total government tax collections.

The final column presents the combined effect of the three behavioral responses. The data presented here show that the tendency of TRA86 to increase the share of taxes paid by upper-income taxpayers in the behaviorfree model is reversed when potential taxpayer behavior is taken into account. Taxpayers earning more than $\$ 200,000$ pay 16 percent of total taxes under the old tax law. This rises to nearly 18 percent under the no-behavior simulation of a fully phased-in TRA86. However, the tax share for this group of taxpayers falls to 15 percent when all behaviors are simulated together. 
In sum, potential taxpayer behavior in response to the changes in the tax law may completely reverse the tendency of TRA86 to increase the tax share at the top. This is exactly opposite to what happened after the tax rate reductions of ERTA. In that case, the behavior-free tax rate effects indicated a reduction in the share of taxes paid by upper-income taxpayers. When the actual results were reported, the reverse occurred, and the tax share paid by upper-income taxpayers rose. Absent the behavioral response to the capital gains tax rate increase, TRA86 would extend the trend of greater tax shares at the top. However, the potential response to the capital gains tax increase is so great that the 1980s may end with the tax share paid by upper-income taxpayers back at the level at which it began the decade.

\section{REFERENCES}

Auten, G., and C. Clotfelter. 1982. Permanent vs. transitory effects and the realization of capital gains. Quarterly Journal of Economics.

Boskin, Michael J. 1973. The economics of the labor supply. In Income maintenance and labor supply, eds. Glen G. Cain and Harold W. Watts. Chicago: Rand McNally.

Burtless, Gary, and Jerry A. Hausman. 1978. The effect of taxation on labor supply: Evaluating the Gary negative income tax experiment. Journal of Political Economy 86: $1103-30$.

Clotfelter, Charles T. 1979. Equity, efficiency, and the tax treatment of in-kind compensation. National Tax Journal 32: 51-60.

- 1983. Tax-induced distortions and the business-pleasure borderline. The American Economic Review 73: 1053-65.

Congressional Budget Office. 1981. A review of the accuracy of treasury revenue forecasts 1963-1978. Washington, D.C.: U.S. Government Printing Office.

. 1983. Forecasting individual income tax revenues: A technical analysis. Washington, D.C.: U.S. Government Printing Office. mimeo. 1986. Effects of the 1981 tax cut on the distribution of income and taxes paid, 1987. CBO replies to Lindsey. Tax Notes May: 496-501.

Economic report of the president. 1987. Washington, D.C.: Government Printing Office.

Feenberg, Daniel, and Harvey S. Rosen. 1982. Alternative tax treatment of the family: Simulation methodology and results. In Simulation methods in tax policy analysis, ed. Martin Feldstein. Chicago: The University of Chicago Press.

Feldstein, Martin. 1978. The rate of return, taxation, and personal savings. The Economic Joumal 88: 482-87.

Feldstein, Martin, and Joel Slemrod. 1978. The lock-in effect of the capital gains tax: Some time series analysis. Tax Notes 8, no. 6: 134-35.

Feldstein, Martin, Joel Slemrod, and Shlomo Yitzhaki. 1980. The effects of taxation on the selling of corporate stock and the realization of capital gains: Reply. The Quarterly Journal of Economics 94: 777-91.

Feldstein, M., and S. Yitzhaki. 1977. The effect of the capital gains tax on the selling and switching of common stock. Journal of Public Economics (February). 
Gwartney, James, and James Long. 1984. Income tax avoidance and an empirical estimation of the Laffer curve. Florida State University, mimeo.

Gwartney, James, and Richard Stroup. 1982. Tax cuts: Who shoulders the burden? Economic Revenue of the Federal Reserve Bank of Atlanta March: 19-27.

Hausman, Jerry A. 1981. Exact consumer's surplus and deadweight loss. The American Economic Review 71: 662-76.

1981. Labor Supply. In How taxes affect economic behavior. Washington, D.C.: The Brookings Institution.

Joint Committee on Taxation. 1981a. General explanation of the Economic Recovery Tax Act of 1981. Washington, D.C.: U.S. Government Printing Office.

1981b. General explanation of the Tax Reform Act of 1986. Washington, D.C.: U.S. Government Printing Office.

Lindsey, Lawrence B. 1987a. Individual taxpayer response to tax cuts: 1982-1984 with implications for the revenue maximizing tax rate. Journal of Public Economics 33 (1987): 173-206.

- 1987b. Capital gains: Rates, realizations, and revenues. In Taxes and capital

formation, ed. Martin Feldstein. Chicago: University of Chicago Press.
$.1987 \mathrm{c}$. Criticizing the CBO analysis of ERTA's effect on the distribution of income and taxes. Tax Notes May: 491-96.

- 1987d. Capital gains taxes under the Tax Reform Act of 1986: Revenue estimates under various assumptions. National Tax Journal.

Long, James E. 1982. Income tax and self employment. National Tax Journal 43: 43.

Minarik, Joseph J. 1981. Capital gains. In How taxes affect economic behavior, eds. Henry J. Aaron and Joseph A. Pechman. Washington, D.C.: The Brookings Institution.

- 1984. The effects of taxation on the selling of corporate stock and the realization of capital gains: Comments. The Quarterly Journal of Economics 99: 93-110.

Pechman, Joseph, and Benjamin A. Okner. 1974. Who bears the tax burden? Washington, D.C.: The Brookings Institution.

Statistics of income. 1960. Washington, D.C.: U.S. Government Printing Office.

1975. Washington, D.C.: U.S. Government Printing Office.

1979. Washington, D.C.: U.S. Government Printing Office.

1980. Washington, D.C.: U.S. Government Printing Office.

1981. Washington, D.C.: U.S. Government Printing Office.

1982. Washington, D.C.: U.S. Government Printing Office.

1983. Washington, D.C.: U.S. Government Printing Office.

1984. Washington, D.C.: U.S. Government Printing Office.

1985. Washington, D.C.: U.S. Government Printing Office.

Turner, Robert $W$. The effect of taxes on the fringe share of compensation. Colgate University, Dept. of Economics, Discussion Paper 88-05. 1988 mimeo.

U.S. Department of Treasury. 1985. Capital gains tax reductions of 1978. Washington, D.C.: U.S. Government Printing Office.

Wyscarver, Roy A. 1982. The Treasury individual income tax simulation model. Washington, D.C.: Office of Tax Analysis. 